\title{
Mosquitoes (Diptera: Culicidae) from crepuscular period in an Atlantic Forest area in Southern Brazil
}

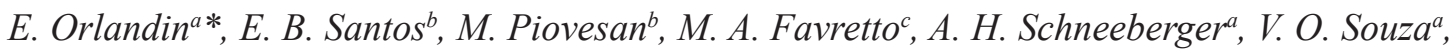 \\ G. A. Mullerd and G. Wagnere,
}

aniversidade do Oeste de Santa Catarina - UNOESC, Campus de Joaçaba, Rua José Firmino Bernardi, CEP 89600-000, Joaçaba, SC, Brazil

bPrograma de Pós-graduação em Entomologia, Centro Politécnico, Universidade Federal do Paraná - UFPR, Jardim das Américas, CEP 81531-980, Curitiba, PR, Brazil

'Programa de Pós-graduação em Ecologia e Conservação, Centro Politécnico, Universidade Federal do Paraná - UFPR, Jardim das Américas, CEP 81531-980, Curitiba, PR, Brazil

'Instituto Federal de Educação, Ciência e Tecnologia Farroupilha, Campus Panambi, CEP 98280-000, Panambi, RS, Brazil

'Laboratório de Doenças Infecciosas e Parasitárias - LDIP, Programa de Pós-graduação Biociências e Saúde,

Universidade do Oeste de Santa Catarina - UNOESC, Campus de Joaçaba, Rua José Firmino Bernardi, CEP 89600-000, Joaçaba, SC, Brazil

fLaboratório de Protozoologia, Universidade do Federal de Santa Catarina - UFSC, Campus João David Ferreira Lima, Trindade, CEP 88040-970, Florianópolis, SC, Brazil

*e-mail: orlandinelton@gmail.com

Received: June 29, 2015 - Accepted: October 14, 2015 - Distributed: February 28, 2017

(With 1 figure)

\begin{abstract}
Crepuscular period is one of the factors that may influence the biting activity of mosquitoes. Many of these insects have a peak activity in this period. The purpose of this study was to investigate the afternoon crepuscular activity of Culicidae in a remaining area of Atlantic Forest in western Santa Catarina, southern Brazil. Moreover, the possible influence of abiotic factors, the abundance and species richness were verified. In order to better analyze the influence of crepuscular period in specific composition and abundance of mosquitoes, the dusk was divided into three periods: pre-sunset, sunset and post-sunset. At the end of the study, nine hundred and eight four specimens distributed in 12 genera and 23 species were collected. Trichoprosopon pallidiventer (Lutz, 1905) (59.76\%), Aedes crinifer (Theobald, 1903) (8.13\%), Ae. scapularis (Rondani, 1848) (5.89\%) were the most abundant species. Spring time presented the greatest abundance and species richness. During the study, among the three periods evaluated, pre-sunset had the greatest abundance and post-sunset the lowest. Pre-sunset and sunset had the greatest similarity between species. Regarding to the abiotic factors evaluated seven and 15 days before sampling, they did not present significant correlation for the three most abundant species. However, temperature had a positive correlation to these species. Moreover, the correlation between collected species and its possible role as vectors of etiological agents of diseases was discussed.
\end{abstract}

Keywords: abiotic factors, Culicidae, Diptera, Hematophagy, Santa Catarina state.

\section{Mosquitos (Diptera: Culicidae) do período crepuscular em área de Floresta Atlântica no sul do Brasil}

\section{Resumo}

O período crepuscular é um dos fatores que pode influenciar na atividade hematofágica dos mosquitos. Muitos desses insetos iniciam ou terminam suas atividades nesse período. O objetivo deste trabalho foi estudar os Culicidae que ocorrem no crepúsculo vespertino em uma área de Floresta Atlântica no oeste de Santa Catarina, sul do Brasil. Além disso, foi analisada a possível influência de fatores abióticos, bem como abundância e riqueza de espécies. Para melhor avaliar a influência do período crepuscular na composição das espécies e na abundância destas, o crepúsculo foi dividido em três períodos: pré-crepúsculo, crepúsculo e pós-crepúsculo. Ao final do estudo foram coletados 984 exemplares distribuídos em 12 gêneros e 23 espécies. Trichoprosopon pallidiventer (Lutz, 1905) (59,76\%), Aedes crinifer (Theobald, 1903) $(8,13 \%)$ e Ae. scapularis (Rondani, 1848) (5,89\%) foram as espécies mais abundantes. A maior abundância e riqueza de espécies se deram na primavera. Dentre os três períodos estudados, o pré-crepúsculo apresentou a maior abundância de mosquitos, em contrapartida, o pós-crepúsculo apresentou a menor abundância. Os períodos pré-crepuscular e crepuscular apresentaram maior similaridade entre si com relação à composição das espécies. Relacionando os fatores abióticos 
e as três espécies mais abundantes, não foi observada correlação significativa nos dados avaliados nos sete e 15 dias anteriores às coletas. Entretanto, a temperatura apresentou uma correlação positiva para estas três espécies. A relação entre as espécies coletadas e a potencial transmissão de agentes etiológicos causadores de doenças foi comentada.

Palavras-chave: fatores abióticos, Culicidae, Diptera, Hematofagia, Santa Catarina.

\section{Introduction}

Culicidae is one of most studied arthropod groups regarding epidemiological interest (Forattini, 2002). The family contains 3,610 described species all over the world (Thompson, 2008) and 470 were described in Brazil (Guedes, 2012). The blood-sucking habit of females necessary for the beginning of vitellogenesis is responsible for granting these insects great importance; whether by the hassle of their bites or the transmission of different etiological agents, which can cause diseases (Forattini, 2002).

The Atlantic Forest biome is considered of high diversity and potentially presents several niches options for the development of immature Culicidae as well as vertebrate fauna, which can be used as hosts for blood-sucking (Bona and Navarro-Silva, 2008). The knowledge about the Culicidae fauna in conservation is important, beyond their epidemiological importance; they can also be used to evaluate the level of changes in an area as biological indicators of these changes whether by the increase of density or its absence (Forattini, 1998).

In addition to biotic factors, such as food availability and immature host plants, seasonality and abiotic factors (as humidity, rainfall and temperature) may also interfere with the greater or lesser activity of many Culicidae species (Beserra et al., 2006). However, the intensity of light is the main factor for changes in the behavior of many species, with the crepuscular period establishing the beginning or the end of activities for these mosquitoes (Forattini et al., 1981; Bona and Navarro-Silva, 2008). Most species of Aedes Meigen, 1818, Psorophora Robineau-Desvoidy, 1827 and Sabethini end its activities with the sunset. On the other hand, several species of de genera Anopheles Meigen, 1818 and Culex Linnaeus, 1758, have crepuscular and nocturnal habits (Forattini, 2002).

Studies related to ecology and mosquitoes behavior were performed by Forattini et al. (1981) in a residual forest area at Ribeira Valley, São Paulo, Brazil, and by Lourenço-de-Oliveira (1984) in Jacarepaguá, Rio de Janeiro, Brazil. These studies, in distinct environments, were carried out to cover the different periods of day and night. Guimarães et al. (2000a, b) have studied climatic factors and the interference of lunar cycle in mosquitoes activities in areas of Serra do Mar, in São Paulo, Brazil. However, there are few studies that deal exclusively with Culicidae fauna of crepuscular period in areas of Atlantic forest.

Guimarães et al. (1997) analyzed the prevalence of Anopheles during the sunset in areas of Itaipu Hydroelectric Plant, Guaira, Paraná, Brazil. Bona and Navarro-Silva (2008), on the other hand, showed the diversity of Culicidae during morning and afternoon crepuscular period, as well as the parity of Anopheles cruzii in Palmito State Park, Paranaguá, Paraná, Brazil. In addition, Müller et al. (2012) evaluated the activity of mosquitoes from the evening sunset period in Tibagi, Paraná, Brazil. Both concluded that the sunset has a strong influence in haematophagic mosquito behavior.

Moreover, molecular analyses suggest that the light affects the expression and deletion of genes involved in diet and metabolism of mosquitoes. The brightness changing unleash the gene expression that control the mosquitoes activities (Ptitsyn et al., 2011; Rund et al., 2011).

Thus, the aim of this study was to identify and establish the influence of climatic elements associated with the crepuscular period on Culicidae community in an Atlantic Forest fragment in southern Brazil.

\section{Material and Methods}

The study was performed in a forest fragment $\left(27^{\circ} 10^{\prime} 22^{\prime}\right.$ S, $51^{\circ} 30^{\prime} 23$ " W), which comprises an area of $2,856,809.33 \mathrm{~m}^{2}$ located about $10 \mathrm{Km}$ from the urban area of Joaçaba municipality, Santa Catarina state, south of Brazil (Joaçaba, 2002). According to Köppen climatic classification, the climate of the city is considered mesothermal humid with hot summer (Cfa), with an average annual temperature of $18{ }^{\circ} \mathrm{C}$, annual precipitation around $2,000 \mathrm{~mm}$, relative annual humidity average of $76 \%$ (Joaçaba, 2003). The region is part of the Atlantic Forest, in the transition area (ecotone) between Araucaria forest and Deciduous forest (Vibrans et al., 2012).

The altitude range in the local is from 700 to $839 \mathrm{~m}$. Also a varied mosaic in its state of preservation, architecture, density, diversity and application characterizes the vegetation. It is covered by primary forest in different states of repair: preserved primary forest; primary forest amended by logging; fragment edge of the forest; glades and ponds. The minimum height of the forest is 20 to $30 \mathrm{~m}$, being found in the upper stratum the presence of Araucaria angustifolia (Bertol.) Kuntze, along with species from the medium stratum: Cedrela fissilis Vell., Diatenopterix sorbifolia Radlk., Ocotea puberula (Rich.) Nees, Cryptocarya moschata Nees et Mart. ex Neess, Ocotea pulchella (Nees) Mez, Matayba elaeagnoides Radlk., Lonchocarpus muehlbergianus Hassl., Campomanesia guazumifoli (Cambess.) O.Berg, Luehea divaricata Mart. et Zucc., Myrocarpus frondosus Allemão, Nectandra megapotamica (Spreng.) Mez, Prunus myrtifolia (L.) Urb., Eugenia pyriformis Cambess., Vitex megapotamica (Spreng.) Moldenke, and Ilex paraguariensis A.St.-Hil. among other species. The vegetation edge has lower stature than the interior forest and it is mainly composed of initial or secondary 
pioneer species, and enables the development of tangles of vines and lianas (Merostachys sp., Chusquea sp. e Abuta sp.). Among the trees are: Allophylus edulis (A. St.-Hil., Cambess. et A. Juss.) Radlk, Allophylus guaraniticus (A. St.-Hil.) Radlk., Campomanesia xanthocarpa O. Berg, Trichilia elegans A. Juss., Sebastiania brasiliensis Spreng., Machaerium paraguariense Hassl., Sapium glandulatum (L.) Morong, among others (Crestani, 2001).

Regarding to the vertebrates that comprise the local fauna there are: Tamandua tetradactyla (Linnaeus, 1758), Galictis cuja (Molina, 1782), Didelphis albiventris Lund, 1840, Dasypus novemcinctus Linnaeus, 1758, Cerdocyon thous (Linnaeus, 1766), Nasua nasua (Linnaeus, 1766), Procyon cancrivorus (G. Cuvier, 1798), Leopardus pardalis (Linnaeus, 1758), Leopardus tigrinus (Schreber, 1775), Puma yagouaroundi (Geoffroy, 1803), Guerlinguetus ingrami Thomas, 1901, Cuniculus paca (Linnaeus, 1766), Dasyprocta azarae Lichtenstein, 1823, Lepus europaeus Pallas, 1778 (Padilha, 2011), besides 129 bird species (Favretto et al., 2008). The area in which the samples were taken is considered the border area, and it is distant about ten meters from a clearing formed by a pond, coming from the degradation of a small artificial lake, with approximately $100 \mathrm{~m}^{2}$.

Mosquitoes were monthly collected between November 2013 and October 2014, during the evening crepuscular period, following sunset time standard provided by the National Institute of Meteorology (INMET, 2014). In order to compare and verify the composition and abundance of species during the evening sunset, it was divided into three periods, each lasting 30 minutes, as follows: pre-dusk period, starting 45 minutes up to 15 minutes before sunset itself; the sunset period, starting 15 minutes before sunset to 15 minutes after sunset, and post-dusk period, starting 15 minutes up to 45 minutes after sunset (adapted from Bona and Navarro-Silva, 2008). Mosquitoes were colected using a light Shannon trap and Castro capture, always when mosquitoes approache the light trap Shannon or in one of the researcheres near to the trap.

The identification of species level was performed using stereoscopic magnifying glass, with the aid of literature, with dichotomous keys from Lane (1953a, b), Galindo et al. (1954), Correa and Ramalho (1956), Consoli and Oliveira (1994) and Forattini (2002). Genera and subgenera of Culicidae were abbreviated according to Reinert (1975).

In order to measure the relative humidity and temperature (medium, minimum and maximum) at the exact time of collection, it was used digital hygrometer term. The monthly record of relative humidity, temperature and rainfall were taken of the automatic station database query from INMET, which is located about five kilometers distant from the study site.

The Pearson Correlation test was used to verify the correlation between abiotic factors (temperature, relative humidity and precipitation) and the crepuscular set, and the three most abundant species The Bray-Curtis cluster analysis was applies to verify the similarity between the specific periods, and UPGMA algorithm was used to draw the distance three based on Bray-Curtis index. The cophenetic correlation coefficient was used to verify the result significance of the cluster analysis. The tests were applied through the use of the Past software, version 2.16.

\section{Results}

Overall 984 specimens were captured distributed in 12 genera: Trichoprosopon (593-60.26\%), Aedes (166-16.87\%), Mansonia (53-5.38\%), Anopheles (46-.68\%), Sabethes (42-4.27\%), Wyeomyia (23-2.34\%), Psorophora (20-2.03\%), Runchomyia (15-1.52\%), Culex (10-1.02\%), Haemagogus (8-0.81\%), Coquillettidia (5-0.51\%) and Uranotaenia (3-0.31\%). Of these, $97.86 \%(\mathrm{n}=963)$ were classified into species, with 23 identified species. The most abundant species were Trichoprosopon pallidiventer (588-59.76\%), followed by Aedes crinifer (80-8.13\%) and Aedes scapularis (58-5.89\%).

Five hundred and eight specimens were found in the pre-dusk period, $51.62 \%$ of the total amount collected. Trichoprosopon pallidiventer was the most numerous $(\mathrm{n}=340)$, followed by Sabethes purpureus (Theobald, 1907) $(\mathrm{n}=34)$ and Ae. scapularis $(\mathrm{n}=28)$. A total of 293 specimens (29.77\%) were collected at sunset. Tr. pallidiventer $(\mathrm{n}=194)$, Ae. crinifer $(\mathrm{n}=41)$ and Ae. scapularis $(\mathrm{n}=15)$ were the most abundant species in this period. Finally, during the post-dusk period, 183 individuals were collected (18.59\%), being Tr. pallidiventer $(\mathrm{n}=54)$, Mansonia titillans (Walker, 1848) $(\mathrm{n}=35)$ e Ae. crinifer $(\mathrm{n}=21)$ the most numerous (Table 1).

According to Bray-Curtis similarity index and cluster analysis a greater similarity between species in pre-dusk and sunset periods (0.64919) was observed than pre-dusk and post-dusk (0.34732) and sunset and post-dusk periods (0.47479) (cophenetic correlation coefficient $=0.90$; Figure 1).

Comparing the species abundance by the seasonality, spring was the season of the year with highest Culicidae abundance, 335 (34.70\%). Autumn was the second one, with $222(22.76 \%)$ collected specimens and then winter,

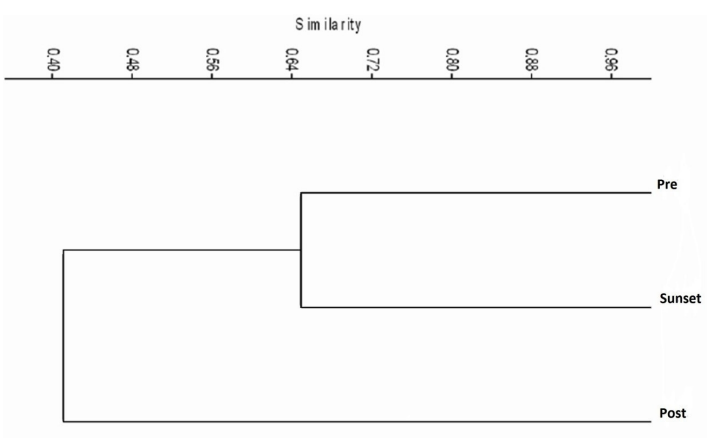

Figure 1. Bray-Curtis similarity index of the sampled crepuscular periods (cophenetic correlation coefficient $=0.90$ ). 
Table 1. Culicidae collected between November 2013 and October 2014 in an Atlantic forest fragment in Joaçaba, Santa Catarina, Brazil.

\begin{tabular}{|c|c|c|c|c|c|}
\hline & Specie & N1 ${ }^{1}$ & $\mathbf{N} 2^{2}$ & $\mathbf{N 3}^{3}$ & $\mathrm{~N}(\%)^{4}$ \\
\hline \multicolumn{6}{|c|}{ Anophelinae } \\
\hline & Anopheles (Anopheles) intermedius (Peryassu, 1908) & 3 & - & 4 & $7(0.71 \%)$ \\
\hline & An. (Nyssorhynchus) argyritarsis Robineau-Desvoidy, 1987 & - & - & 1 & $1(0.10 \%)$ \\
\hline & An. (Nys.) benarrochi (Ruiz et al, 2005) & - & 3 & 10 & $13(132 \%)$ \\
\hline & An. (Nys.) lutzi (Cruz, 1901) & 6 & 4 & 9 & $19(1.93 \%)$ \\
\hline & An. (Nys.) strodei Root, 1926 & - & - & 3 & $3(0.30 \%)$ \\
\hline & $A n$. sp. & 1 & - & 2 & $3(0.30 \%)$ \\
\hline \multicolumn{6}{|c|}{ Culicinae: Aedini } \\
\hline & Aedes (Ochlerotatus) crinifer (Theobald, 1903) & 18 & 41 & 21 & $80(8.13 \%)$ \\
\hline & Ae. (Och.) fluviatilis (Lutz, 1904) & 2 & 1 & 2 & $5(0.50 \%)$ \\
\hline & Ae. (Och.) scapularis (Rondani, 1848) & 28 & 15 & 15 & $58(5.9 \%)$ \\
\hline & Ae. (Och.) serratus (Theobald, 1901) & 5 & 8 & 4 & $17(1.72 \%)$ \\
\hline & Ae. (Och.) sp. & - & - & 2 & $2(0.20 \%)$ \\
\hline & Ae. (Och.) terrens (Walker, 1856) & 1 & - & 3 & $4(0.40 \%)$ \\
\hline & $\begin{array}{l}\text { Haemagogus (Conopostegus) leucocelaenus } \\
\text { (Dyar \& Shannon, 1924) }\end{array}$ & 3 & 4 & 1 & $8(0.81 \%)$ \\
\hline & Psorophora (Janthinosoma) ferox (Humboldt, 1819) & 13 & 6 & 1 & $20(2.03 \%)$ \\
\hline \multicolumn{6}{|c|}{ Culicinae: Culicini } \\
\hline & Culex sp. & 1 & 4 & 5 & $10(1.01 \%)$ \\
\hline \multirow[t]{3}{*}{$\begin{array}{l}\text { Culicinae: } \\
\text { Mansoniini }\end{array}$} & $\begin{array}{l}\text { Coquillettidia (Rhynchotaenia) venezuelensis } \\
\text { (Theobald, 1912) }\end{array}$ & - & - & 5 & $5(0.51 \%)$ \\
\hline & Mansonia (Mansonia) pseudotitillans (Theobald, 1901) & - & - & 3 & $3(0.30 \%)$ \\
\hline & Ma. (Man.) titillans (Walker, 1848) & 11 & 4 & 35 & $50(5.08 \%)$ \\
\hline \multicolumn{6}{|c|}{ Culicinae: Sabethini } \\
\hline & $\begin{array}{l}\text { Runchomyia (Runchomyia) humboldti } \\
\text { (Lane \& Cerquiera, 1942) }\end{array}$ & 12 & 2 & 1 & $15(1.52 \%)$ \\
\hline & Sabethes (Peytonulus) aurescens (Lutz, 1905) & 5 & 1 & - & $6(0.61 \%)$ \\
\hline & Sa. (Sabethes) purpureus (Theobald, 1907) & 34 & 2 & - & $36(3.66 \%)$ \\
\hline & Trichoprosopon (Trichoprosopon) pallidiventer (Lutz, 1905) & 340 & 194 & 54 & $588(59.76 \%)$ \\
\hline & Tr. sp. & 4 & 1 & - & $5(0.51 \%)$ \\
\hline & Wyeomyia (Phoniomyia) bourrouli Lutz, 1905 & 1 & - & - & $1(0.10 \%)$ \\
\hline & Wy. (Pho.) theobaldi (Lane \& Cerqueira, 1942) & 3 & 1 & - & $4(0.40 \%)$ \\
\hline & Wy. (Wyeomyia) limai Lane \& Cerqueira, 1942 & 15 & 2 & - & $17(1.73 \%)$ \\
\hline & Wy. sp. & 1 & - & - & $1(0.10 \%)$ \\
\hline \multicolumn{6}{|c|}{$\begin{array}{l}\text { Culicinae: } \\
\text { Uranotaeniini }\end{array}$} \\
\hline & $\begin{array}{l}\text { Uranotaenia (Uranotaenia) pulcherrima } \\
\text { Lynch-Arribalzaga, } 1891\end{array}$ & 1 & - & 2 & $3(0.30 \%)$ \\
\hline & Total & 508 & 293 & 183 & $984(100 \%)$ \\
\hline
\end{tabular}

${ }^{1}$ pre-dusk period. ${ }^{2}$ sunsetperiod. ${ }^{3}$ post-duskperiod. ${ }^{4}$ total among all (\%).

with $219(22.74 \%)$ specimens. Interestingly, summer had the lowest abundance of specimens (187-19.41\%) (Table 2).

No significant correlation was observed when analyzed the environmental variables and the abundance of Culicidae (based on the three most abundant species), regarding seven and fifteen days before collection. However, a significant correlation between the abundance of Culicidae and environmental variables at the time of collection was observed. In addition, the average and minimum temperature showed a significant positive correlation for Ae. scapularis e Tr. pallidiventer. Maximum temperature was positively correlated for Ae. scapularis. On the other hand, the humidity had a negative correlation for Tr. pallidiventer and Ae. scapularis (Table 3).

\section{Discussion}

The division of evening crepuscular period in three sets (pre-dusk, sunset and post-dusk) showed a clear transition of species that occurs during the crepuscular hours and demonstrated the transition of the biting activity that occurs between species of mosquitoes with diurnal 
Table 2. Seasonality distribution of Culicidae in the forest fragment in Joaçaba, Santa Catarina, Brazil.

\begin{tabular}{|c|c|c|c|c|}
\hline Specie & Spring (\%) & Summer (\%) & Autumn (\%) & Winter (\%) \\
\hline Ae. crinifer & $30(3.11 \%)$ & $7(0.72 \%)$ & $3(0.31 \%)$ & $40(4.15 \%)$ \\
\hline Ae. fluviatilis & $3(0.31 \%)$ & $1(0.1 \%)$ & $1(0.1 \%)$ & - \\
\hline Ae. scapularis & $50(5.18 \%)$ & - & $3(0.31 \%)$ & $5(0.51 \%)$ \\
\hline Ae. serratus & $13(1.34 \%)$ & - & $4(0.41 \%)$ & - \\
\hline Ae. terrens & $2(0.21 \%)$ & - & $1(0.1 \%)$ & $1(0.1 \%)$ \\
\hline An. argyritarsis & - & - & - & $1(0.1 \%)$ \\
\hline An. benarrochi & $2(0.21 \%)$ & $8(0.83 \%)$ & - & $3(0.31 \%)$ \\
\hline An. lutzi & $12(1.24 \%)$ & - & - & $7(0.72 \%)$ \\
\hline An. intermedius & $5(0.51 \%)$ & $1(0.1 \%)$ & - & $1(0.1 \%)$ \\
\hline An. strodei & - & $2(0.21 \%)$ & $1(0.1 \%)$ & - \\
\hline Co. venezuelensis & - & $2(0.21 \%)$ & $3(0.31 \%)$ & - \\
\hline Hg. leucocelaenus & $1(0.10 \%)$ & - & $7(0.72 \%)$ & - \\
\hline Ma.pseudotitillans & - & $2(0.21 \%)$ & $1(0.1 \%)$ & - \\
\hline Ma. titillans & $36(3.73 \%)$ & $7(0.72 \%)$ & $4(0.41 \%)$ & $3(0.31)$ \\
\hline Ps. ferox & $3(0.31 \%)$ & $11(1.14 \%)$ & $5(0.52 \%)$ & $1(0.1 \%)$ \\
\hline Ru. humboldti & $13(1.34 \%)$ & - & $1(0.1 \%)$ & $1(0.1 \%)$ \\
\hline Sa.purpureus & $1(0.10 \%)$ & $8(0.83 \%)$ & $22(2.28 \%)$ & $5(0.51 \%)$ \\
\hline Sa. aurescens & $4(0.41 \%)$ & - & - & $2(0.20 \%)$ \\
\hline Tr. pallidiventer & $153(15.85 \%)$ & $137(14.22 \%)$ & $158(16.40 \%)$ & $140(14.53 \%)$ \\
\hline Ur. pulcherrima & $2(0.21 \%)$ & - & - & $1(0.1 \%)$ \\
\hline Wy. bourrouli & - & - & $1(0.1 \%)$ & - \\
\hline Wy. theobaldi & $2(0.21 \%)$ & $1(0.1 \%)$ & $1(0.1 \%)$ & - \\
\hline Wy. limai & $3(0.31 \%)$ & - & $6(0.62 \%)$ & $8(0,83 \%)$ \\
\hline Total & $335(34.70 \%)$ & $187(19.41 \%)$ & $222(23.05 \%)$ & $219(22.74 \%)$ \\
\hline
\end{tabular}

Table 3. Pearson correlation of environmental variables at the time of collection and the most abundant species identified in the forest fragment in Joaçaba, Santa Catarina, Brazil.

\begin{tabular}{lcccc}
\hline & $\begin{array}{c}\text { Average of } \\
\text { temperature } \\
\left({ }^{\circ} \mathbf{C}\right)\end{array}$ & $\begin{array}{c}\text { Maxium } \\
\text { temperature } \\
\left({ }^{\circ} \mathbf{C}\right)\end{array}$ & $\begin{array}{c}\text { Minimum } \\
\text { temperature } \\
\left({ }^{\circ} \mathbf{C}\right)\end{array}$ & $\begin{array}{c}\text { Relative humidity } \\
(\%)\end{array}$ \\
\hline Ae. crinifer & -0.39 & 0.98 & -0.51 & 0.08 \\
Ae. scapularis & 0.97 & -0.72 & 0.99 & -0.84 \\
Tr. pallidiventer & 0.96 & -0.28 & 0.91 & -0.99 \\
\hline
\end{tabular}

and nocturnal habits. Also the highest similarity of species between pre-dusk and sunset sets described in this study indicates that a few species with diurnal habits extend their activities beyond the sunset. It was expected, since the crepuscular functions as a time of transition between the species of diurnal and nocturnal habits (Bona and Navarro-Silva, 2008). However, Tr. pallidiventer was found in all sets, differently proposed by Forattini et al. (1968) that describes the Tr. pallidiventer only with diurnal habits. It may indicate that the brightness factor is not a preponderant factor for biting activity to $T r$. pallidiventer. Likewise, average temperature, air humidity and rainfall do not seem to influence on seasonal fluctuations in the abundance of Tr. pallidiventer, (Santos et al., 2014). This study also shows a correlation of mean and minimum temperature and the presence of this species.
Anopheles lutzi and Ma. titillans have nocturnal habits, but their activities began during the pre-dusk set, which corroborates to the data discussed above. This indicates that the brightness is not the main factor responsible for initiating the process of seeking hosts and blood meal. Forattini (2002), Guimarães et al. (2000b) and Santos et al. (2014) indicate that a set of climatic factors, such as temperature and humidity, may influence the activity of mosquitoes. According to Bona and Navarro-Silva (2008) and Muller et al. (2012), the transition of the species with daytime activity to those with nocturnal activity, occurs after dusk, and the light would not be the only determining factor for this change.

Aedes crinifer activity was observed during the crepuscular period in all seasons but it is most abundant during winter and spring. However, Loetti et al. (2007) indicate that it is more abundant during autumn and 
summer, and Silva and Lozovei (1998) suggest that it is during the fall and spring. Also, a positive correlation with maximum temperature was observed, similar to observed by Silva and Lozovei (1998). Furthermore, Santos et al. (2014) reported that Ae. crinifer was the most abundant species and the peak of abundance was in the hottest hours of the morning, which corroborates the observed in the current study.

Although Ae. scapularis is more abundant in the pre-dusk set, it was sampled in the other two sets, indicating their activity in the course of the crepuscular period. Previous studies have shown that Ae. scapularis is found throughout the day and its highest activity was described in the crepuscular period than other periods (Forattini and Gomes, 1988; Silva and Lozovei, 1998). Concerning seasonality, Ae. scapularis was collected in the spring, between September and December, indicating a greater association with climate conditions of this period and the abundance of this specie. This similarity was observed to Forattini and Gomes (1988), which sampled this specie in highest abundance between June and November. Alike to what described by Guimarães et al. (2000b), which describe a positive correlation among the abundance of this specie and temperature. However, in the current study, the relative humidity showed a negative correlation with the specie abundance

In addition to climatic factors involved in the Culicidae activities, the environment characteristic may influence their presence. The presences of potential hosts are also fundamental for the distribution of mosquitoes (Burkett-Cadena et al., 2013). In this way, heterogeneous environments allow the development of distinct species of mosquitoes with different hematophagous habits, behavioral and oviposition (Marchi et al., 2010). In Addition, the diversity of habitat found in the studied fragment may contribute to the presence of species with different habits

During the pre-dusk set, several species of Sabethini tribe were collected, with an accentuated decrease of its abundance during sunset and barely seen in the post-dusk. Species sampled belonging to Sabethini tribe share many characteristics, like day habit and natural breeding, such as water accumulated in leaf axils, tree holes and bamboo internodes. Also, it is important to emphasize that these species are exclusively found in sylvatic environment (Forattini, 2002).

Species of Anopheles found in the present study reveal nocturnal habits and usually is developed on the ground in puddles and ponds. However, larvae of An. argyritarsis (Silva et al., 2008) and An. strodei (Lopes, 1997) in artificial breeding were reported. Moreover, Mansoniini species found in the fragment, has its growing in perennial aquatic environments which have aquatic plants, and develop very well in anthropogenic environments (Wermelinger et al., 2012; D'Avila and Gomes, 2013).

The activity of Aedini occurred during all the crepuscular sets, being Aedes species found in abundance during all periods, while $H g$. leucocelaenus and Ps. ferox abundance decreasing in the advance of sets, similar to observed by
Consoli and Oliveira (1994). Aedes species found in this study are adapted to anthropogenic environments and they are found in several artificial breeding sites (Lopes, 1997; Zequi et al., 2005). While Hg. leucocelaenus breeds are found in accumulated water at tree holes (Silva and Lozovei, 1999) and in residual patches of forest (Forattini and Gomes, 1988) Ps. ferox rise in depressions on the ground, in shady environments (Consoli and Oliveira, 1994) and it is commonly f found in modified environments (Forattini et al., 1978).

The presence of Ae. crinifer and Ae. scapularis may indicate the different stages of regeneration of the area and anthropogenic modifications in surrounding area. Forattini et al. (1995) observed a large increase of Ae. scapularis in an area within intense environmental changes. But, in a study with mosquito larvae in the same sample area of this study, Santos et al. (2013) reported an abundance of Ae. scapularis only in natural breeding, like a temporary lagoon existent in the area. Furthermore, as proposed by Gomes et al. (2009), more studies about the Ae. crinifer habits are necessary due to its versatility to develop in both natural and unnatural environment.

Among the species collected, ten have been reported as potential vectors of distinct pathogens. Anopheles argyritarsis and An. strodei are considered secondary vectors of malaria (Oliveira Pereira and Rebêlo, 2000), $\mathrm{Hg}$. leucocelaenus is vector of sylvatic yellow fever (YF) (Gomes et al., 2009), Oc. scapularis, Co. venezuelensis, Ps. ferox and Ma. pseudotitillans of encephalitis (Guedes, 2012), Ma. titillans has been found carrying the virus of Venezuelan encephalitis (Consoli and Oliveira, 1994), Oc. fluviatilis can transmit the etiological agent of malaria in chickens, under laboratory conditions (Consoli and Oliveira, 1994). Also, Ae. serratus s.l. is considered a secondary vector of YF and encephalitis and specimens of this species were found naturally infected with YF in Rio Grande do Sul (Cardoso et al., 2010). The presence of Hg. leucocelaenus and Ae. serratus s.1., vectors of the sylvatic YF (Guedes, 2012), reinforce the importance of monitoring this area, due to its location in the transition area of YF and for being close to urban areas, which have been found Ae. aegypti, vector of urban YF (Santa Catarina, 2015).

Despite the most abundant species were collected in almost all seasons, they were found more abundantly in one season, except Tr. pallidiventer that remained constant throughout the year. This indicates a higher activity of these species in certain periods of the year, which is probably related to major adaptations and reproductive success in these periods. Regarding the potential vectors, they are more abundant in the spring and found in all crepuscular sets. . In addition, spring may be the season with the greatest risk of disease transmission by these species.

In conclusion, the brightness influences the peak of Culicidae activities through the fluctuations of abundance and species composition in the crepuscular periods. Also, the humidity and temperature are correlated with the abundance of them and their possible extension of the 
biting activity period. Additionally, the environmental factors involved on the regulation of Culicidae activity are important since the environmental changes wrought by men can determine new epidemiological scenarios.

\section{Acknowledgements}

The authors are grateful to Universidade do Oeste de Santa Catarina for granting the Scientific Initiation scholarship PIBIC/UNOESC (Art.170) for E.O. and to Renato Lins for English review.

\section{References}

BESERRA, E.B., CASTRO JUNIOR, J.R., SANTOS, J.W., SANTOS, T.S. and FERNANDES, C.R.M., 2006. Biologia e exigências térmicas de Aedes aegypti (L.) (Diptera: Culicidae) provenientes de quatro regiões bioclimáticas da Paraíba. Neotropical Entomology, vol. 35, no. 6, pp. 853-860. http://dx.doi.org/10.1590/ S1519-566X2006000600021. PMid:17273720.

BONA, A.A. and NAVARRO-SILVA, M.A., 2008. Diversidade de Culicidae durante os períodos crepusculares em bioma de Floresta Atlântica e paridade de Anophles cruzii (Diptera: Culicidae). Revista Brasileira de Zoologia, vol. 25, no. 1, pp. 40-48. http:// dx.doi.org/10.1590/S0101-81752008000100007.

BURKETT-CADENA, N.D., MCCLURE, C.J.W., ESTEP, L.K. and EUBANKS, M.D., 2013. Hosts or habitats: What drives the spatial distribution of mosquitoes? Ecosphere, vol. 4, no. 2, pp. 1-16. http://dx.doi.org/10.1890/ES13-00009.1.

CARDOSO, J.C., ALMEIDA, M.A., SANTOS, E., FONSECA, D.F., SALLUM, M.A., NOLL, C.A., MONTEIRO, H.A., CRUZ, A.C., CARVALHO, V.L., PINTO, E.V., CASTRO, F.C., NUNES NETO, J.P., SEGURA, M.N. and VASCONCELOS, P.F., 2010. Yellow Fever Virus in Haemagogus leucocelaenus and Aedes serratus Mosquitoes, Southern Brazil. Emerging Infectious Diseases, vol. 16, no. 12, pp. 1918-1924. http://dx.doi.org/10.3201/ eid1612.100608. PMid:21122222.

CONSOLI, R.A.G.B. and OLIVEIRA, R.L., 1994. Principais mosquitos de importância sanitária no Brasil. Rio de Janeiro: Fiocruz. 228 p.

CORREA, R.R. and RAMALHO, G.R., 1956. Revisão de Phoniomyia Theobald, 1903 (Diptera, Culicidae, Sabethini). Folia Clinica et Biologica, vol. 25, pp. 1-176.

CRESTANI, E., 2001. Laudo Fitofisionômico e Florístico do Remanescente Florestal do Posto Agropecuário de Joaçaba. Joaçaba. Dados não publicados.

D'AVILA, F.A. and GOMES, A.C., 2013. Seasonality of Mansonia titillans during dam construction, Biritiba Mirim, São Paulo State, Brazil. Biota Neotropica, vol. 13, no. 1, pp. 70-73. http://dx.doi. org/10.1590/S1676-06032013000100007.

FAVRETTO, M.A., ZAGO, T. and GUZZI, A., 2008. Avifauna do Parque Natural Municipal Rio do Peixe, Santa Catarina, Brasil. Atualidades Ornitológicas, vol. 141, pp. 87-93.

FORATTINI, O.P., 1998. Mosquitos Culicidae como vetores emergentes de infecções. Revista de Saúde Pública, vol. 32, no. 6, pp. 497-502. http://dx.doi.org/10.1590/S0034-89101998000600001. PMid:10349140.
FORATTINI, O.P., 2002. Culicidologia médica: identificação, biologia, epidemiologia. São Paulo: EdUsp, vol. 2. 860 p.

FORATTINI, O.P. and GOMES, A.C., 1988. Biting activity of Aedes scapularis (Rondani) and Haemagogus mosquitoes in Southern Brazil (Diptera: Culicidae). Revista de Saúde Pública, vol. 22, no. 2, pp. 84-93. http://dx.doi.org/10.1590/S003489101988000200003. PMid:2905827.

FORATTINI, O.P., GOMES, A.C., GALATI, E.A., RABELLO, E.X. and IVERSSON, L.B., 1978. Estudos ecológicos sobre mosquitos Culicidae no sistema da Serra do Mar, Brasil. 1. Observações no ambiente extradomiciliar. Revista de Saúde Pública, vol. 12, no. 3, pp. 297-325. http://dx.doi.org/10.1590/ S0034-89101978000300005. PMid:751174.

FORATTINI, O.P., GOMES, A.C., SANTOS, J.L.F., GALATI, E.A.B., RABELLO, E.X. and NATAL, D., 1981. Observações sobre atividade de mosquitos Culicidae, em mata residual no Vale do Ribeira, São Paulo, Brasil. Revista de Saúde Pública, vol. 15, no. 6, pp. 557-586. http://dx.doi.org/10.1590/S003489101981000600001. PMid:7344068.

FORATTINI, O.P., KAKITANI, I., MASSAD, E. and MARUCCI, D., 1995. Studies on mosquitoes (Diptera: Culicidae) and anthropic environment. 10 -Survey of adult behaviour of Culex nigripalpusand other species of Culex (Culex) in Southeastern Brazil. Revista de Saúde Pública, vol. 29, no. 4, pp. 271-278. http:// dx.doi.org/10.1590/S0034-89101995000400003. PMid:8729276.

FORATTINI, O.P., LOPES, O.S. and RABELLO, E.X., 1968. Investigações sobre o comportamento de formas adultas de mosquitos silvestres no Estado de São Paulo, Brasil. Revista de Saúde Pública, vol. 2, no. 2, pp. 111-173. http://dx.doi.org/10.1590/ S0034-89101968000200002. PMid:5709516.

GALINDO, P., FRANKLIN, S., BLANTON, F.S. and PEYTON, E.L., 1954. A revision of the Uranotaenia of Panama with notes on other American species of the genus. Annals of the Entomological Society of America, vol. 47, no. 1, pp. 107-771. http://dx.doi. org/10.1093/aesa/47.1.107.

GOMES, A.C., PAULA, M.B., VITOR NETO, J.B., BORSARI, R. and FERRAUDO, A.S., 2009. Culicidae (Diptera) em área de barragem em Santa Catarina e no Rio Grande do Sul. Neotropical Entomology, vol. 38, no. 4, pp. 553-555. http://dx.doi.org/10.1590/ S1519-566X2009000400021. PMid:19768280.

GUEDES, M.L.P., 2012. Culicidae (Diptera) no Brasil: Relações entre diversidade, distribuição e enfermidades. Oecologia Australis, vol. 16, no. 02, pp. 283-296. http://dx.doi.org/10.4257/ oeco.2012.1602.07.

GUIMARÃES, A.E., GENTILE, C., LOPES, C.M. and MELLO, R.P., 2000a. III. Ecology of mosquitoes (Diptera: Culicidae) in areas of Serra do Mar State Park, State of São Paulo, Brazil. III - daily biting rhythms and lunar cycle influence. Memórias do Instituto Oswaldo Cruz, vol. 95, no. 6, pp. 753-760. http:// dx.doi.org/10.1590/S0074-02762000000600002. PMid:11080757.

GUIMARÃES, A.E., MELLO, R.P., LOPES, C.M. and GENTILE, C., 2000b. I. Ecology of mosquitoes (Diptera: Culicidae) in areas of Serra do Mar State Park, State of São Paulo, Brazil. Monthly frequency and climatic factors. Memórias do Instituto Oswaldo Cruz, vol. 95, no. 1, pp. 1-16. PMid:10656698.

GUIMARÃES, A.E., MELLO, R.P., LOPES, C.M., ALENCAR, J. and GENTILE, C., 1997. Prevalência de Anofelinos (Diptera: Culicidae) no Crepúsculo Vespertino em Áreas da Usina Hidrelétrica de Itaipu, no Município de Guaíra, Estado do Paraná, Brasil. Memórias do Instituto Oswaldo Cruz, vol. 92, no. 6, pp. 
745-754. http://dx.doi.org/10.1590/S0074-02761997000600004. PMid:9580488.

INSTITUTO NACIONAL DE METEOROLOGIA - INMET, 2014 [viewed 28 October 2014]. [online]. Available from: http:// www.inmet.gov.br/portal/

JOAÇABA. Prefeitura Municipal, 2002 [viewed 9 December 2014]. Lei $n^{\circ} 2.800$, de 11 de abril de 2002. Cria no municipio de Joaçaba o Parque Natural Municipal do Vale do Rio do Peixe com os limites que o especifica e dá outras providências. Diário Oficial [online], Joaçaba, 11 de abril de 2002. Available from: http:// www.jusbrasil.com.br/legislacao/750888/lei-2800-02-joacaba-sc

JOAÇABA. Secretaria de Estado de Desenvolvimento Regional - SDR, Governo do Estado de Santa Catarina, 2003 [viewed 28 October 2014]. Caracterização regional [online]. Available from: http://docweb.epagri.sc.gov.br/website_cepa/publicacoes/ diagnostico/JOACABA.pdf

LANE, J., 1953a. Neotropical Culicidae. São Paulo: EdUsp, vol. $1.548 \mathrm{p}$.

LANE, J., 1953b. Neotropical Culicidae. São Paulo: EdUsp, vol. 2. $1112 \mathrm{p}$.

LOETTI, V., BURRONI, N. and VEZZANI, D., 2007. Seasonal and daily actitivy of human-biting mosquitoes in a wetland system in Argentina. Journal of Vector Ecology, vol. 32, no. 2, pp. 358-365. http://dx.doi.org/10.3376/1081-1710(2007)32[358:SADAPO]2.0 .CO;2. PMid:18260528.

LOPES, J., 1997. Ecologia de mosquitos (Diptera, Culicidae) em criadouros naturais e artificiais de área rural do norte do estado do Paraná, Brasil: VI. Coletas de larvas no peridomicílio. Revista Brasileira de Zoologia, vol. 14, no. 3, pp. 571-578. http://dx.doi. org/10.1590/S0101-81751997000300007.

LOURENÇO-DE-OLIVEIRA, R., 1984. Alguns aspectos da ecologia dos mosquitos (Diptera: Culicidae) de uma área de planície (Granjas Calábria), em Jacarepaguá, Rio de Janeiro. 1. Freqüência comparativa das espécies em diferentes ambientes e métodos de coleta. Memórias do Instituto Oswaldo Cruz, vol. 79, no. 4, pp. 479-490. http://dx.doi.org/10.1590/S0074-02761984000400014.

MARCHI, M.J., MÜLLER, G.A. and MARCONDES, C.B., 2010. Mosquitos (Diptera: Culicidae) de uma futura Unidade de Conservação em área de Mata Atlântica no sul do Brasil. EntomoBrasilis, vol. 3, no. 2, pp. 34-37. http://dx.doi.org/10.12741/ebrasilis.v3i2.77.

MULLER, G.A., BONA, A.C.D., MARCONDES, C.B. and NAVARRO-SILVA, M.A., 2012. Crepuscular activity of culicids (Diptera, Culicidae) in the peridomicile and in the remaining riparian forest in Tibagi river, State of Paraná, Brazil. Revista Brasileira de Entomologia, vol. 56, no. 1, pp. 111-114. http://dx.doi.org/10.1590/ S0085-56262012005000006.

OLIVEIRA-PEREIRA, Y.N. and REBELO, J.M.M., 2000. Espécies de Anopheles no município de Pinheiro (Maranhão), área endêmica de malária. Revista da Sociedade Brasileira de Medicina Tropical, vol. 33, no. 5, pp. 443-450. http://dx.doi.org/10.1590/S003786822000000500006. PMid:11064581.

PADILHA, L., 2011. Mamíferos. In: M.A. FAVRETTO. Parque Natural Municipal Rio do Peixe, Joaçaba, SC: fauna de vertebrados. 1st ed. Joaçaba: Edição do Autor, vol. 1, pp. 58-117.

PTITSYN, A.A., REYES-SOLIS, G., SAAVEDRA-RODRIGUEZ, K., BETZ, J., SUCHMAN, E.L., CARLSON, J.O. and BLACK, W.C. 4th., 2011. Rhythms and synchronization patterns in gene expression in the Aedes aegypti mosquito. BMC Genomics, vol.
12, no. 1, pp. 153. http://dx.doi.org/10.1186/1471-2164-12-153. PMid:21414217.

REINERT, J.F., 1975. Mosquito generic and subgeneric abbreviations (Diptera: Culicidae). Mosquito Systematics, vol. 7, pp. 105-110.

RUND, S.S., HOU, T.Y., WARD, S.M., COLLINS, F.H. and DUFFIELD, G.E., 2011. Genome-wide profiling of diel and circadian gene expression in the malaria vector Anopheles gambiae. Proceedings of the National Academy of Sciences of the United States of America, vol. 108, no. 32, pp. 421-430. http://dx.doi. org/10.1073/pnas.1100584108. PMid:21715657.

SANTA CATARINA. Secretaria do Estado da Saúde. Diretoria de Vigilância Epidemiológica - DIVE, 2015 [viewed 14 September 2015]. [online]. Available from: http://www.dive.sc.gov.br/

SANTOS, E.B., FAVRETTO, M.A. and D'AGOSTINI, F.M., 2013. Larvas de culicídeos do Parque Natural Municipal Rio do Peixe, Joaçaba, Santa Catarina. In: M.A. FAVRETTO and E.B. SANTOS. Estudos da Fauna do Oeste de Santa Catarina; microrregiões de Joaçaba e Chapecó. Campos Novos: Edição dos Autores, pp. 69-86.

SANTOS, E.B., FAVRETTO, M.A. and MULLER, G.A., 2014. Mosquitos (Díptera: Culicidae) do Parque Natural Municipal do Vale do Rio do Peixe, Joaçaba, Santa Catarina, Brasil, com novos registros para o estado. Evidência, vol. 14, pp. 21-34.

SILVA, M.A. and LOZOVEI, A.L., 1998. Mosquitos (Diptera, Culicidae) capturados com isca humana em área preservada de Curitiba, Paraná. Revista Brasileira de Zoologia, vol. 15, no. 4, pp. 965-976. http://dx.doi.org/10.1590/S0101-81751998000400015.

SILVA, M.A. and LOZOVEI, A.L., 1999. Ocorrência de Haemagogus (Conopostegus) leucocelaenus (Dyar \& Shannon) e Toxorhynchites (Lynchiella) theobaldi (Dyar \& Knab) em ocos de árvore em capão de mata, Curitiba, Paraná, Brasil. Revista Brasileira de Zoologia, vol. 16, no. 1, pp. 257-267. http://dx.doi.org/10.1590/ S0101-81751999000500018.

SILVA, J.S., ACEL, A.M., GUIMARÃES, A.E. and ALENCAR, J., 2008. Encontro de larvas de Anopheles (Nyssorhynchus) argyritarsis em criadouros artificiais no Estado de Mato Grosso. Revista da Sociedade Brasileira de Medicina Tropical, vol. 41, no. 3, pp. 313-314. http://dx.doi.org/10.1590/S0037-86822008000300019. PMid: 18719817.

THOMPSON, F.C., 2008 [viewed 10 December 2014]. The Diptera site: the biosystematic database of world Diptera: nomenclator status statistics [online]. Available from: www.sel.barc.usda.gov/ diptera/names/Status/bdwdstat.htm

VIBRANS, A.C., MCROBERTS, R.E., LINGNER, D.V., NICOLETTI, A.L. and MOSER, P., 2012. Extensão original e remanescentes da Floresta Estacional Decidual em Santa Catarina. In: A.C. VIBRANS, L. SEVEGNANI, A.L. GASPER and D.V. LINGNER. Inventário Florístico Florestal de Santa Catarina: Floresta Estacional Decidual. Blumenau: EdiFurb, vol. 2, pp. 25-32.

WERMELINGER, E.D., BENIGNO, C.V., MACHADO, R.N., CABELLO, P.H., MEIRA, A.M., FERREIRA, A.P. and ZANUNCIO, J.C., 2012. Mosquito population dynamic (diptera: culicidae) in a eutrophised dam. Brazilian Journal of Biology = Revista Brasileira de Biologia, vol. 72, no. 4, pp. 795-799. http://dx.doi.org/10.1590/ S1519-69842012000500003. PMid:23295506.

ZEQUI, J.A.C., LOPES, J. and MEDRI, I.M., 2005. Imaturos de Culicidae (Diptera) encontrados em recipientes instalados em mata residual no município de Londrina, Paraná, Brasil. Revista Brasileira de Zoologia, vol. 22, no. 3, pp. 656-661. http://dx.doi. org/10.1590/S0101-81752005000300021. 